\title{
Professional Titles for Women Seafarers in the Croatian and Montenegrin Media
}

\author{
Milena Dževerdanović Pejović
}

This paper aims to present a comparative view of the English and Croatian female maritime ranks aboard ship in the language of media. Regarding the English language, male/ masculine forms have also been normative and gender-neutral; in other words, they refer to both genders (pilot, lawyer, captain). However, changes in the society and "embarkation" of women on board masculine professions have been reflected in language changes as well. The female professional titles are derived from the masculine forms. Social changes and gender awareness politics simultaneously took place in both countries, resulting in the rise of women seafarer number on board ships.

This paper presents a review of the comparative analysis of Montenegrin and Croatian texts. The results show that Croatian media use the female titles more frequently and regularly, while in Montenegrin texts their use is somewhat sporadic. The reasons for this are also found in the ethnical picture of the two countries. Montenegrin society still rests on patriarchal values

\section{KEY WORDS}

$\sim$ Gendered discourse

$\sim$ Professional titles

$\sim$ Media discourse

$\sim$ Women seafarers

University of Montenegro, Faculty of Maritime Studies, Kotor, Montenegro e-mail:milenadz@ac.me

doi: 10.7225/toms.v09.n02.017

This work is licensed under (cc) BY and the authors of the texts prefer using masculine forms as gender-neutral. What is more, the Republic of Croatia accessed the European Union in 2013, and it was undoubtedly required to implement institutional regulations relating to minimizing gender discrimination in the society and public discourse. Finally, it was concluded that linguists and language planners have to differentiate between justified and non-justified use of female forms as they can assume the pejorative meaning.

\section{INTRODUCTION}

In modern times, when women have fought for equal status in male-dominated professions, it is also necessary to designate the corresponding female titles. Naming female titles has become a current issue of modern linguistics, politics, media, and diplomacy.

The traditional solution that has been applied so far is the use of masculine grammatical gender as an unmarked category, i.e. women were "identified" through men. Therefore, as far as language regulations are concerned, the usage of masculine forms for men in linguistics was an unmarked choice, a language norm. On the other side, women were marked, and in a way, they were identified "whether through man, father, husband, lover" (Perović, 2006). The use of masculine pronouns to refer to men's and women's professions and the use of the "neutral" generic pronouns ("he") to refer to both men and women, have become implicit and taken for granted in the English language. Linguists have argued since the rise of the feminist movement in the 1970s and 1980s that language has been mainly created for men. 
Knowing that women in seafaring have started to board ships and advance in the hierarchy of licensed crew members, the language has to adapt to this new social and cultural changes. In the academic world, it is well known that publishers advise authors to avoid language which might be discriminatory or gender-sensitive, such as "he" for general use.

This new non-linguistic ambient, which was triggered by feminist theories from the last decades of the 20th century, had an impact on the seafaring language. The author of this paper has come to grip with a very delicate subject, but the attitude taken here is not a feminist one. On the contrary, the aim is to point to the necessity of harmonizing social and language trends.

The language material explored in the Montenegrin and Croatian languages, includes many forms for emerging masculine and feminine professions. However, the names for ranks used in a discourse of military forces and shipping mainly use the masculine form - in the linguistic terms, an unmarked and neutral one. However, the tendency is not only regional, it is still present in other patriarchal and traditional countries.

Finally, it was established that the language used in both media encourages female forms rather than the generic use of the masculine forms for both genders. It seems that "much of the media nowadays are concerned to appear non-sexist and to promote the interests of women" (Sunderland, 2004).

\section{LANGUAGE AND GENDER}

Gender issues in the twenty-first century are a part of globalised politics. "They are all part of a much larger movement: the movement to create a world in which principles of partnership, rather than domination and submission, are the primary ones" (Eisler, 2005, p. 24).

Are there different communicative patterns and differences between men and women in everyday and professional setting? For sure, a whole set of contextual factors define the speech styles of men and women (Weatherall, 2001).

Empirical research about gender and language is marked by a whole set of polarized concepts ascribed to men (rational, assertive, authoritative) and women (talkative, emotional, affectionate). The assumptions about ways of talking, tone of voice, sense of humour, small talk and the fundamental constituents of the feminine, as opposed to masculine ways of speaking, have been the subject of analysis of many linguists. According to Hofstede (1998, p. 10), this male-female power syndrome is expressed in some countries to a greater or lesser extent, and are by-and-large masculine (Japan, Germany, the United States) or feminine (Nordic countries).

These premises, based on research into public language, and which are of relevance to the topic of our paper, have shifted into research into specialized languages within different workplaces, particularly those traditionally occupied by men. Stereotypes about masculine and feminine language terms should not be regarded as opposite poles of the same continuum. Masculine language is not rational or neutral, nor is feminine discourse emotional and uncontrolled. Holmes carried out research on workplaces in New Zealand, and one of the conclusions relevant to the analysis in this article was that both women and men exploit different methods of discourse according to the types of interaction and context; however, slight discrimination against women pervades. This calls for social transformation (Holmes, 2006).

There is no doubt that gender issues require a sociolinguistic perspective, and the rise of new disciplines and human resource management has permeated various approaches. The rise of women to leading positions and, what is more, in "hypermasculine work cultures" (Maaranen and Tienari, 2020) has come into focus more than ever before, particularly from the point of questioning women's roles in adapting to new positions.

Having the above in mind, women are sometimes in doubt as to which style of behaviour to adopt. In some cases, they are urged to choose assertive or more masculine styles of discourse in the public sphere, but when they do so, they are perceived as aggressive and confrontational (Coates, 2013, p. 202). On the other side, traditional views, rooted in myth and fairy tales, state that a woman succeeds when she is silent and obedient. This is well illustrated by the fairy tale of "The Seven Swans", when a sister saves her seven brothers from a spell by sewing shirts for them and staying speechless. Otherwise, if she had uttered anything, she would have failed in her intention (Lakoff, 2003, p. 162).

\section{WOMEN IN SEAFARING}

In the modern education system, women are trained in the same navigation and engineering courses as men. They are assigned many different jobs on board ships. Still, one may assume that professional equality of men and women on board is yet to come. The figures are higher than they used to be, but data about female captains and chief officers are difficult to obtain. According to the data available on the website of the International Maritime Organization (IMO), continuous genderrelated programmes and campaigns are aimed at empowering women in the maritime sector and making women more representative of the seafaring sector. As posted on the IMO website, only $2 \%$ of seafarers are women (IMO, 2019). IMO has been actively contributing to supporting women in the maritime industry and encouraging women to "turn the current tide". One of the programmes, called "Women in Maritime", invites women to share their experiences on board and make their stories visible to other women. History's long tradition of men's domination 
at sea needs constant activities and efforts in order to achieve gender equality and mitigate the discrimination against women in the maritime sector.

Further figures showing women's employment on board are rather discouraging. Data states that women choose to sail on cruise ships rather than on merchant ships, which are still regarded as a male-dominated arena. Women are underrepresented in the seafaring sector and make up only $18 \%$ of the workforce (International Labour Office, 2003). The International Transport Workers' Federation has also supported the participation of women. It has established female support through maritime trade unions, with the aim to promote women's rights and maternity policies, and to set processes in place to deal with sexual harassment. Despite all these efforts, it seems that gender policies to a great extent differ from company to company and lack a national institutional legislation framework.

\section{TWO SIDES OF THE COIN}

The attitude held in this paper is that a lot has been achieved in the field of women's independence and empowerment, especially in male-dominated professions.

As noticed by Savić (2011), when we refer to a "woman pilot", "woman lieutenant", "woman colonel", or "woman general", the use of the feminine forms is an idiomatic feature of the language, but what is more important, it is a reflection of the new era in the social hierarchy.

In order to adapt the new social changes to language changes, the issue of naming female occupational titles is becoming challenging for linguists, researchers, editors, publishers, and journalists. Inconsistencies in this domain are evident. However, as regarded by the social and linguistic ambiance of the Republic of Croatia and the Republic of Montenegro, there are two sides to the coin. On the one side, women find that using female titles will contribute to their better positioning in the society and professional life. Other women think that the use of the feminine forms rather than masculine ones is not in accordance with the language. They find that the use of feminine words might be an expression of political will rather than actual language needs.

In addition, it must be mentioned that the social media have raised women's profile. Websites that carry testimonies of maritime women on board and in professional organizations, and maritime blogs (Nautilus International, Gender at sea blog spot, Women in Maritime) have also provided practical support for women seafarers.

Subtle manipulations with female occupational forms are more prominent on the intertextual level. Thus, in media reporting, authors may inconsistently use feminine and masculine forms throughout the narrative, depending on the rhetorical effect they wish to achieve. Mijušković (2013) observes that when the authors of media texts wish to obtain formality of discourse, they use masculine forms (as with English "judge": Montenegrin "sudija", Croatian: "sudac"), but if the female referent is blamed for some activity, she becomes in English a "female judge" (Montenegrin: "sudinica", Croatian: "sutkinja"). The use of female forms particularly bears pejorative connotation in the news about women at the highest diplomatic positions whose professional integrity is for some reason under question (English: "female minister" - Montenegrin: "ministarka" or Croatian: "ministrica"; English: "female ambassador" - Montenegrin: "ambasadorka", Croatian: "ambasadorica", and English: "female director" - Montenegrin and Croatian: "direktorica". The more the privacy of the female is scrutinized, the more female occupational titles are used.

In the article about reasons why the ship is referred to as "she" (Dževerdanović-Pejović, 2017), it is noted that underinformed men on ships have called women captains "Sir" since the 1980s because they did not know that "Ma'am" was the appropriate word to use. The word "lady" was archaic and referred to class status rather than to professional occupation. Knowing the centuries-long tradition of using the feminine pronoun "she" to refer to a woman, women also find it is about time to change the discriminatory "she" into "it". Calling the ship "she" is the act of attributing female qualities perceived as weaker to the ship. Such a linguistic view opposes the new position of women on board, after centuries-long isolation from the shipping world.

A fundamental top-down change was Lloyds List changing this naming practice, from calling ships "she" to using "it" (Hibberd and Woolcock, 2002).

There is no doubt that language is constitutive and reflective of social changes (Holmes, 2006) and that it plays a significant role in gender roles, particularly in masculine-dominated work cultures.

\section{METHODOLOGY AND THEORETICAL FOUNDATIONS}

Theoretical foundations outlined in this paper rely on the work of linguists Savić (2011), Šehović (2003), KuzmanovićJovanović (2013), Perović (2006, 2009), Sunderland (2004) and Lakoff (2003), and other relevant institutional documents dealing with gender policy issues. Gender-based knowledge is the starting basis for the media interpretation of female vocations in the maritime setting. The corpus is based on the 20,300word Montenegrin and Croatian online reports about women seafarers.

There are considerably fewer examples from the Montenegrin texts $(8,400$ words) because the Republic of Montenegro has a smaller fleet, and Montenegrin seafarers focus on the foreign maritime market. On the other hand, Croatia has 
a larger fleet and considerably more seafarers, with about 154 ships in the Croatian merchant fleet (The Economic Value of the Croatian Shipping Industry, 2018). For this reason, the examples from the Croatian language were readily accessible for linguistic analysis.

The focus of the research was on the formation and actual use of female titles to designate jobs aboard ships. Target words were selected according to their frequency in the relevant national regulation books.

In order to provide a qualitative analysis of the results, the author relied on the relevant official sources from the Montenegrin and Croatian resources (Government Rulebooks and Regulations, Offices for Gender Equality, official dictionaries).

\section{THE COMPARATIVE VIEW}

As regards the internet articles about women in seafaring, the authors of the texts present these women in a sensationalist fashion in the headlines. The discursive function of headlines is to attract the readers' interest and catch their attention. The headlines in our corpus are usually accompanied by appealing images of women standing at the wheel of the ship.

Some representative examples from our corpus are Women taking over the helm ("Žene prezimaju kormilo"), Croatian daughter-in-law entered into history of navigation ("Hrvatska snaha ušla u povijest pomorstva), Croatian officers on board one of the most luxurious cruise ships ("Hrvatske časnice na jednom od najluksuznijih kruzera"), Montenegro: Humanity and brevity in a woman's manner ("Crna Gora: Čojstvo i junaštvo na ženski način").

The following example is taken from a Croatian portal and tells a story about the Croatian female third officer on board:

1. It is challenging to set limits on board, whether you give orders or set limits so that people listen to you and everything works well.

("Na brodu je dosta teško naći tu granicu, hoćete li zapovijedati ili naći neku granicu po kojoj vas i ljudi slušaju i sve štima.")

The female officer says that male colleagues treat her with respect, and the very presence of a woman on board brings a homely atmosphere.

2. She behaves very well and does her job well. There is peace on the bridge - no questions or objections.

("Zna se ponašati i vrlo dobro se nosi sa svojim poslom. Na mostu je mir. Nema pogovora, nema prigovora.")

The above examples show that women tend to fit into a male-dominated atmosphere on board. While working with their male mates, they chose to be regarded as people, not women, and even hid their feminine appearances while at work (Kitada 2013). We found this situation in our corpus:
3. I am not sure how to answer this question. For sure, while I am on board and in uniform, I consider myself a female officer in the same way that I look at my colleagues, whether they are males or females. Gender is not what defines an officer, but his knowledge and competencies in carrying out tasks and duties.

("Nisam sigurna kako da odgovorim na ovo pitanje. Zasigurno dok sam na brodu, kad sam u uniformi, ja sebe smatram časnicom, isto kao što smatram i ostale kolege, bilo muške ili ženske. Spol nije ono što definira časnika, već njegovo znanje i vještina u izvršavanju zadataka, odgovornosti i obaveza.")

The following examples prove that in the Croatian texts about women seafarers, all authors use female forms consistently. Apparently, women cope well with the male-dominated atmosphere aboard ships:

4. She has never been affected by the stories: "Baby, the sea is not for women". She strongly wishes to become a female captain of the ship.

(“Nisu je pokolebale priče:"Mala, nije more za žene”; uporna je u svom naumu. Želi postati kapetanica broda.")

5. A lovely female seafarer will soon embark, and she will keep good memories of both ship captains.

("Simpatična pomorkinja uskoro će ponovno na brod, a u izvrsnom sjećanju ostala su joj obojica zapovjednika broda.")

The linguistic situation between the Montenegrin and Croatian seafarers aboard ships is similar. Most female titles are derived from the masculine, and use the suffixes -ica , - ka, and -inja. However, language and cultural distinctions have to be made between the term "kapetanica" (female captain) in the Croatian and Montenegrin languages. Namely, in the Montenegrin language, the traditional etymological meaning of the "female captain" ("kapetanica") in the coastal region of the Republic of Montenegro (the Boka Bay) was that of the "captain's wife". It had a pejorative connotation and referred to a captain's wife waiting for the return of her husband (Dževerdanović, 2017). Likewise, this meaning in the Montenegrin language seems to have been imprinted in the modern language. For this reason, some Montenegrin female captains prefer to use a gender-neutral masculine form rather than the female one ("kapetanica"). The same refers to the "female minister" (Montenegrin: "ministarka"), which is an old-fashioned style that implies a minister's wife.

Regarding written material about the female seafarers in Montenegrin online journals, the usage of masculine generic forms is more common. It is interesting to note that women themselves use the masculine forms in the text although the author uses female forms in the headline: "Female cadets from Montenegro learn to become officers on the famous sailing ship Sea Cloud" ("Kadetkinje iz Crne Gore uče za oficire na čuvenom jedrenjaku Sea Cloud.")

6. I started 17 years ago as a sailor on board "Sea Cloud". Afterwards, I sailed on board other school training ships, sailing 
ships, then on cruise ships. I returned to "Sea Cloud" as a First Officer.

("Počela sam prije 17 godina kao mornar na brodu "Sea Cloud". Nakon toga sam prešla na druge školske brodove jedrenjake, pa na klasične putničke brodove. Vratila sam se na ovu kompaniju gdje sam prvi oficir")

There are examples of the random usage of the masculine and feminine occupational titles in the narrative, when the journalists unsystematically choose between female and masculine forms.

7. A female lieutenant of the corvette, the First Officer in the Navy of the Republic of Montenegro, was on board ship from 05th to 13th August.

("Na brodu od 5. do 13. avgusta, bila je ukrcana i poručnica korvete, prvi oficir u Mornarici Vojske Crne Gore.")

Many Montenegrin officers and seafarers opted to board cruise ships due to attractive salaries and comfort that the cruise ship offers. It is interesting to note that feminine titles are consistently used for the jobs traditionally performed by women. 8. In the beginning, she worked as an assistant waitress, and after a few months, she changed her workplace and became a hostess in the restaurant. Snežana works as a cabin stewardess.

(“Ona je radila kao pomoćna konobarica, da bi već nakon par mjeseci, promijenila radno mjesto i postala hostesa $u$ restoranu. Snežana radi kao cabin stewardess").

\subsection{Montenegrin and Croatian Rulebooks}

The use of gender-sensitive language in media is partly reinforced by the global policy aimed at making women more visible in the media and public space. Many portals and publications are aimed at raising media and public awareness about the equality of women (Ured za ravnopravnost spolova Žene i mediji, 2020).

As previously said, both languages employ derivational suffixes to form female nouns for certain professions, which were primarily reserved for men. Since the breakup of the former Yugoslavia, there have been two main choices that the countries in question have made. The language creators designed their independent paths in the creation of the standard languages. The most salient division was between Eastern and Western variant - the former inclined toward Turkish and Arabic language, the latter toward Latin and German words (Greenberg, 2004, p. 53).

In this light, some suffixes and borrowings from the Eastern and Western variants overlap. The most distinctive difference is, therefore, between the Eastern variant, as in -ica, -ka, -inja in the Montenegrin language (female minister -"ministarka", female doctor -"doktorica", female professor - "profesorica") and Western variant -ica in the Croatian language (female officer -"časnica", female captain -"kapetanica"). Sometimes, the suffixes -ica, and -ka are used interchangeably in the Montenegrin language such as (female psychologist - "psihološk-inja", "psiholog-ica").

After an insight into the rulebooks for seafarers of the Republic of Croatia (Pravilnik o zvanjima i svjedodžbama o osposobljenosti pomoraca, 2013), and the Republic of Montenegro (Pravilnik o zvanjima i uslovima za sticanje zvanja i uslovima za sticanje zvanja i izdavanje ovlašćenja, 2015), it was established that both documents use masculine generic forms for female and male seafaring ranks. Neither of the texts has an official statement, usually placed at the end of the documents, that the generic use of the masculine pronoun "he" throughout the text, or the use of masculine nouns is not an act of gender discrimination. This statement should be included in the documents of public discourse, or more precisely, in the administration discourse (Čaušević and Zlotrg, 2011). Also, it is recommended that in legal acts and regulations, both genders should be used at the beginning of the text while the rest of the text should employ masculine forms - "Where decisions on job assignments or other decisions on the rights and obligations of civil servants are adopted, the title of a post shall be used in the masculine and feminine gender-" (Act on Gender Equality, 2003).

In this light, the most representative examples for maritime professions in the Republic of Croatia, referring to all the three departments on board ships are: captain/master ("zapovjednik"), officer ("časnik"), seafarer ("pomorac"), crew member ("član posade"), chief engineer ("upravitelj stroja"), engineer ("časnik stroja"), cadet ("vježbenik"), ship's electrician ("brodski električar"), radio operator ("radio officer"), helmsman ("kormilar"), seaman ("mornar"), fitter ("brodski mehaničar"), oiler ("mazač").

In the Montenegrin language, masculine forms refer to both genders and are very similar to the mentioned Croatian terms: captain ("kapetan", "zapovjednik"), officer ("oficir"), seafarer ("pomorac"), crew member ("član posade"), chief engineer ("upravitelj mašine"), inžinjer ("engineer"), cadet ("kadet"), ship electrician ("brodski električar"), radio operater ("radio officer"), kormilar ("helmsman"), seaman ("mornar"), fitter ("brodski mehaničar"), oiler ("mazač").

In order to promote the idea of gender equality in the language, which should equally treat masculine and feminine forms in naming professional titles, the following table proposes the comparative view of female titles in the Montenegrin and Croatian languages extensively employed in the language of media and public discourse. References were made to the Montenegrin online dictionary (2010), Hrvatski jezični portal, and National classification of professions of the Republic of Croatia (2010). 
However, the search of our corpus confirmed that the use of "female sea wolf" in Montenegrin connotes attractive women and, thus, has an aesthetic or fashion-related meaning. It may refer to bikini women posing on the luxurious yachts rather than to women from the seafaring profession. It might have a sexist meaning again; therefore, in this case, it is the socially unexpected behaviour that bans the use of certain language phrases.

Unlike the Republic of Croatia, which entered the European Union, the Republic of Montenegro has become a candidate for membership. Many national programmes and projects are in progress, and the drafting of gender-related acts is in the focus of the current Montenegrin national policy.

The above stated means that institutional framework and legislation must take into account women's empowerment and the mitigation of gender discrimination, particularly at workplaces. This goal can be obtained if the societies stop to see women as a marked category, that is, whether linguistically or socially dependent on men, and encourage the concept of the masculine category as primary (Burr, 2003).

Dedication to real equality of the genders at all levels and in all social domains, especially of women in terms of their maternity rights and equal treatment in a professional setting, is a part of the Gender Equality Strategy (2018). The Council of Europe will, therefore, strive to encourage women's visibility in participation in all aspects of public and private life. This particularly relates to raising the importance of women's equal participation in education, decision-making policies, and choice of career. This is particularly important in countries with dominant patriarchal roles and gender stereotypes, as women are regarded as housewives and are discriminated in their professional roles by motherhood. Particular attention should be paid to addressing sexist language and eliminating sexism in the media and public discourse.

In that sense, it can be said that the more regular occurrence of female forms in the Croatian media discourse can partly be explained by the fact that the language policy of the Republic of Croatia, with the accession of this country to the European Union, has adopted new standards of women's affirmation in all spheres of the society.

\section{CONCLUSION}

The comparative view of the use of feminine forms and representation of women in Montenegrin and Croatian media, shows that there is a similar linguistic ambience in both countries, and that language of media reporting, rather than of the official documents, more consistently applies derivative forms for female gender. Language changes reflect social changes which have made the roles of women more visible. Professional networks and establishment of many "women in maritime" organisations worldwide, also bolstered female representatives in the public discourse in the analysed corpora of the two countries.

It can be concluded that the Republic of Croatia has a somewhat more regular language forms for the female maritime professions in public discourse and a higher language sensibility compared to other ex-Yugoslav states (Šehović, 2003). For example, the word for "seaman" has a female equivalent in the Croatian language ("pomorkinja"), derived from the masculine form, which is not the case in Montenegrin.

As regards language planning in both countries, it has been suggested that both language rules and language intuition should be used in the designation of professional occupations. In this light, female maritime professions are derived from the masculine forms in the official regulations for seafarers in both countries. In addition, in both languages, the use of the feminine forms in some examples could acquire a negative connotation ("female server", and "female oiler").

The commonly-held attitude is that women still represent a novelty on board ship. Women are regarded as wives, daughters or sisters, and are generally considered to be in some kind of relationship with men. Examples for this include the pejorative connotation for the female captain ("kapetanica"), implying a captain's wife in analogy with a female minister implying a minister's wife.

Given the lack of research material, particularly on the part of the Montenegrin corpus, we may still expect that this empirical study will be complemented with more extensive comparative research in the future.

Having in mind the view of language as a social category reflecting the world we live in, it is worth noting how social changes are reflected on the language. On a modern ship, which is still seen as a male-dominated world or man's world, it is worth exploring the pace at which the female ranks transit from being bad luck to being equal with male mates on board.

In conclusion, the view taken in this paper supports the attitude that we must be careful when choosing between the dichotomy pairs, i.e., masculine and feminine roles. Whenever we are in doubt whether to use female or masculine forms, we should take into account language intuition and make the women's role transparent and recognized.

\section{REFERENCES}

Act on Gender Equality, 2003. Narodne novine, 116, pp.4229-4232. Available at: http://www.ilo.org/dyn/natlex/natlex4.detail?p_lang=\&p_isn=64728.

Basturkmen, H., 2010. Developing Courses in English for Specific Purposes. Available at: http://dx.doi.org/10.1057/9780230290518.

Burr, E., 2003. French. Gender and language politics in France. IMPACT: Studies in Language and Society, pp.119-139. Available at:

http://dx.doi.org/10.1075/impact.11.09bur. 
Čaušević J., Zlotrg S., 2011. Priručnik za prevladavanje diskriminacije u obrazovanju, medijima i pravnim dokumentima, Sarajevo: NIK Grafit.

Coates, J., 2013. Women, Men, and Language: A Sociolinguistic Account of Gender Differences in Language, London and New York: Routledge.

Dževerdanović-Pejović, M., 2017. Linguistic Facts as a Reflection of Changes in Seafaring: Is a ship still a "she"? The Mariner's Mirror, 103(3), pp.313-322. Available at: http://dx.doi.org/10.1080/00253359.2017.1340427.

Eisler, R., 2005. The Economics of the Enlightened Use of Power. Enlightened Power: How Women are Transforming the Practice of Leadership, pp. 21-39, San Francisco: Jossey-Bass.

Gender at sea blog. Nautilus International. Available at: https://www.nautilusint. org/en/.

Gender Equality Strategy 2018-23, 2018. Council of Europe. Available at: https://rm.coe.int/prems-093618-gbr-gender-equality-strategy-2023-weba5/16808b47e1, accessed on: 11 April 2020

Greenberg, R., 2004. Language and Identity in the Balkans, Oxford: Oxford University Press.

Hibberd A., Woolcock N., 2002. Lloyd's List sinks the tradition of calling ships 'she', The Telegraph. Available at: https://www.telegraph.co.uk/news/uknews/1388373/ Lloyds-List-sinks-the-tradition-of-calling-ships-she.html.

Hofstede, G., Arrindell, W., 1998. Masculinity and Femininity: The Taboo Dimension of National Culture, London: Sage Publications.

Holmes, J., 2006. Gendered Talk at Work: Constructing Social Identity through Workplace Interaction, USA: Blackwell Publishing.

Hrvatski jezični portal, 2020. Available at: http://hjp.znanje.hr/index. php?show=search_by_id\&id=ellkXBI\%3D, accessed on: 12 March 2020.

International Labour Office, 2003. Woman Seafarer: Global employment policies and practice, Geneva: ILO.

International Maritime Organization, 2019. Women in Maritime. London: International Maritime Organization, available at: http://www.imo.org/en/OurWork/ TechnicalCooperation/Pages/WomenInMaritime.aspx.

Kitada, M., 2013. Code of behaviour at sea: women seafarers' shipboard identity management. WMU Journal of Maritime Affairs, 12(2), pp.213-227. Available at: http://dx.doi.org/10.1007/s13437-013-0044-7.

Kuzmanović Jovanović, A., 2013. Rodno osetljiv jezik u sektoru bezbednosti, Beograd: Beogradski centar za bezbedonosnu politiku.
Lakoff, R., Language, Gender, and Politics: Putting "Women" and"Power" in the Same Sentence. The Handbook of Language and Gender, pp.160-178. Available at: http://dx.doi.org/10.1002/9780470756942.ch7.

Maaranen, A. \& Tienari, J., 2020. Social media and hyper-masculine work cultures. Gender, Work \& Organization. Available at:

http://dx.doi.org/10.1111/gwao.12450.

Mijušković, S., 2013. Registar zvanja, zanimanja i titula žena, Podgorica: Ministarstvo za ljudska i manjinska prava.

National Classification of professions of the Republic of Croatia, 2010. Narodne novine 03(103), 09(75).

Perović, S., 2006. On je rekla: Upotreba rodno-senzitivnog jezika, Podgorica: Kancelarija za ravnopravnost polova Vlade Republike Crne Gore.

Perović, S., 2009. Jezik u akciji, Podgorica: CID.

Pravilnik o zvanjima i svjedodžbama o osposobljenosti pomoraca, 2013. Narodne novine 13(130)

Pravilnik o zvanjima i uslovima za sticanje zvanja i izdavanje ovlašćenja za članove posade pomorskih brodova, 2013. Službeni list Crne Gore, 2013(55).

Savić, S., 2011. Predlog za upotrebu rodno osetljivog jezika u vojsci: činovi žena. Bezbednost Zapadnog Balkana, 19, pp. 46-56.

Savić, S., 2011. Žene u avijaciji: Gracije ili borbene avijatičarke? Rod i bezbednost 3. Available at: http://www.bezbednost.org/upload/document/bilten_rod_i bezbednost_3.pdf.

Šehović, A., 2003. Upotreba mocionih sufiksa (u nomina agentis et professionis) u savremenom razgovornom bosanskom jeziku, Pismo, 1(1), pp. 73-92.

Sunderland, J., 2004. Gendered Discourse, New York: Palgrave Macmillan.

The Economic Value of the Croatian Shipping Industry, 2018. Oxford Economics, London, UK. Available at: http://csamarenostrum.hr/userfiles/files/Croatian\%20 Shipping\%20Presentation.pdf.

The Montenegrin Dictionary, 2010. Podgorica: Ministry of Education of the Government of the Republic of Montenegro.

Ured za ravnopravnost spolova Vlade Republike Hrvatske: Žene i mediji. Available at: https://ravnopravnost.gov.hr/istaknute-teme-i-projekti-11/zene-i-mediji/3267.

Weatherall, A., 2005. Gender, Language and Discourse. Available at: http://dx.doi.org/10.4324/9780203988817. 